\title{
The Evaluation of Energy Efficiency Policies in the Building Sector: A Regional Analysis Based on the Stochastic Frontier Approach and on the Energy Environmental Kuznets Curve (EKC) and Policy Implications
}

\author{
Pietro Falconi \\ Faculty of Economics, University of Tuscia, S.M. in Gradi n.4, Viterbo 01100, Italy
}

Corresponding Author Email: p.falconi@unitus.it

https://doi.org/10.18280/ti-ijes.652-441

Received: 7 March 2021

Accepted: 16 May 2021

\section{Keywords:}

building sector, energy efficiency, energy environmental Kuznets curve, panel data, stochastic frontier analysis

\begin{abstract}
The promotion of the Energy Efficiency is one of the priorities of EU energy policy to fight the Climate Change and make Europe climate neutral by 2050 (EC 2020). The civil sector offers high potential for energy efficiency improvement and the buildings are responsible for about $40 \%$ of the EU's energy consumption, and $36 \%$ of greenhouse gas emissions (EC 2020). In Italy the civil sector (residential and tertiary together), are responsible for approximately $45 \%$ of final energy consumption and $17.5 \%$ of Italy's $\mathrm{CO}_{2}$ emissions, has a potential in reducing energy consumption of approximately 5,7 Mtoe compared to the base scenario in 2030.

The core research question is: "Are national and local energy efficiency policies effective in reducing aggregate energy consumption at regional level in the civil sector?" From the policy maker's point of view, it is important to understand the effectiveness of the policy instruments introduced to promote energy efficiency. The research framework is based on the frontier analysis and its main objective is to econometrically estimate for the period 2010 to 2017 the energy efficiency level for the civil sector in the Italy regions. The estimates confirm the effectiveness of policy instruments, represented by tax deductions and economic incentives, in creating high potential for energy savings from reduced inefficiency in the civil sector.
\end{abstract}

\section{INTRODUCTION}

The Energy Efficiency is seen one of the top priorities of the EU and Member States. The EU energy and climate change package has set goals to cut greenhouse gas (GHG) emission at least 55\% (compared to 1990) and to improve energy efficiency at least $32.5 \%$ by 2030 to becoming climate neutral by 2050 . The European Union (EU) has undertaken numerous initiatives aimed at encouraging the transition process towards cleaner energy sources.

The increasing attention to energy efficiency from an environmental point of view has led over the years an increasingly role of Energy Efficiency to fight climate change.

The main programmatic EU measures are the European Commission (EC) package "Clean Energy for all Europeans" (EU regulation issued to support the Energy Performance of Buildings Directive (2010/31/EU (EPBD)) and the Energy Efficiency Directive (2012/27/EU), were amended, as part of the "Clean energy for all Europeans package".)and the Integrated National Energy and Climate Plan (INECP) (To meet the EU's energy and climate targets for 2030, EU countries need to establish a 10-year integrated national energy and climate plan (INECP) for the period from 2021 to 2030. Introduced under the Regulation on the governance of the energy union and climate action (EU/2018/1999), the rules required the final INECP to be submitted to the Commission by the end of 2019.) sent by each State member to the EC. Energy Efficiency in the current worldwide pandemic scenario with the COVID - 19 crisis remains a key pillar for a EU long term sustainable and climate neutral economy. In the civil sector the EU building stock offers high potential for energy efficiency improvements. Most of the existing buildings are old and rely on fossil fuels for heating and cooling, and use old technologies and wasteful appliances.

Covid 19 offers a unique opportunity to make civil buildings more efficient, comfortable and safety with the financial resources available (Next Generation EU). The role of the building is changing and becoming more central, the homes are often turned on workstation in teleworking and so we are spending more and more time in them.

In the INECP sent by Italy to EU it is highlighted the key role of the civil sector for the reduction of energy consumption with the realization of energy efficiency investments: "The civil sector, along with transport, is identified as the main sector for efficiency improvement measures, with a reduction in energy consumption of approximately 5.7 Mtoe compared with the base scenario for 2030 and a commitment to gradually eliminate oil for heating purposes. In particular, the residential sector contributes to 3.3 Mtoe of this decrease, whereas the tertiary sector reduces the projections for its consumption by 2.4 Mtoe, thanks to structural renovation measures and the installation of heat pumps, as well as a greatly improved efficiency of end-use devices".

The scope of this paper is to estimate the impact of energy policies instruments on the estimated level of underlying energy efficiency in the Italian building sector.

The theoretical framework underlying this research is based on the Stochastic Frontier Approach (SFA). Filippini and Hunt 
[1] have introduced the SFA to define and measure the energy efficiency. Whereas frontier analysis is developed on the estimation of parametric best practice frontier for the use of energy where the level of energy efficiency is computed as the difference between the actual energy use and the predicted energy use. This work, as proposed by Filippini and Hunt [2], uses an econometric approach to estimate the level of energy efficiency at a disaggregated level for the 20 Italian regions in the period 2010-2017.

The paper is organised as follows. Section 2 provides an overview of the main policy in Italy supporting the speed up of energy efficiency investments in the building sector at regional and local level. Section 3 explain the theoretical framework of the Stochastic Frontier used to measure energy efficiency. Section 4 explains regional model to be estimated with the Stochastic Frontier Approach. Section 5 provides the estimation results, while Section 6 sets out the main policy implications.

\section{ENERGY-EFFICIENCY POLICY MEASURES IN ITALY}

The National Energy Strategy defines how each EU country contributes to the 2030 energy and climate objectives set by the EC. In Italy energy, including energy efficiency policies, is a competence shared between the Regions and the State. In Table 1 are illustrated the policy instruments promoting energy efficiency more relevant for building sector that will be used to construct the policy indicator considered in the econometric analysis at regional level.

The Energy Efficiency policy instruments, governance level (national, regional and local), sector (industrial, residential and tertiary), typology (obligation scheme and alternative) and nature (financial and other) are the information reported in Table 1.

Ecobonus and Thermal Account are the main measures in place managed by the Central Government in Italy to promote energy efficiency in the civil sector (residential plus tertiary).

The Ecobonus, managed by ENEA, is a tax deduction measure of the amount of the energy efficiency investment, to promote and boost buildings renovation. It is the main measure of energy requalification for the residential sector, with over 4 million interventions carried out, approximately 42.5 billion investments made and approximately $17,700 \mathrm{GWh} /$ year saved since the start of the mechanism (2007).

The Thermal Account 2.0, managed by GSE, promotes energy efficiency and the production of thermal energy from renewable sources through subsidies to the investments. The beneficiaries of the mechanism are public administrations, businesses and individuals and the available funds are 900 million euros per year.

The adoption of the Regional Energy and Environmental Plan (PEAR), the adherence to the Covenant of Mayors and the participation in programs co-financed by the European Structural and Investment Funds (European Regional Development Fund, Regional Operational Programs, etc.) are the initiatives undertaken at regional and local level aimed at promoting energy efficiency.

With PEAR' adoption each Region defines the strategy to achieve the Europe 2030 targets for climate change and energy sustainability, including measures related to the buildings and facilities renovation. Each PEAR foresees, according to the specific regional objectives, investments promoting energy efficiency such as the renovation of public buildings, schools, hospitals and social housing.

The Covenant of Mayors is a voluntary agreement through which the signatories put in place policies and actions to accelerate the decarbonisation of their territories, strengthening their ability to adapt to the impacts of climate change and allowing their citizens to access a safe, sustainable and accessible energy. Sustainable Energy and Climate Action Plan (SECAP) is the implementation instrument of the Covenant of Mayors which reserves a leading role in the energy requalification of private residential and public buildings, including hospital, schools and social housing.

In response to the recent pandemic crisis caused by the Coronavirus, the EC has decided to allocate additional resources through the recovery assistance package for cohesion and the territories of Europe called REACT-EU, some of these are for the energy efficiency promotion in the tertiary sector.

Table 1. Energy Efficiency measures: level, sector, typology and nature

\begin{tabular}{|c|c|c|c|}
\hline E.E. Measure & $\begin{array}{c}\text { Level }(\mathrm{N}= \\
\text { National, } \mathrm{R}= \\
\text { Regional and } \mathrm{L} \\
\text { = Local) }\end{array}$ & Sector & Typology Nature \\
\hline Ecobonus & $\mathrm{N}$ & $\begin{array}{l}\text { Residential, } \\
\text { Tertiary }\end{array}$ & Alternative Fiscal \\
\hline $\begin{array}{l}\text { National E.E. } \\
\text { Fund }\end{array}$ & $\mathrm{N}$ & $\begin{array}{l}\text { Residential, } \\
\text { Tertiary }\end{array}$ & Alternative Financial \\
\hline PREPAC & $\mathrm{N}$ & Tertiary & Alternative Financial \\
\hline $\begin{array}{l}\text { Thermal } \\
\text { Account }\end{array}$ & $\mathrm{N}$ & Tertiary & Alternative Financial \\
\hline $\begin{array}{l}\text { White } \\
\text { Certificates }\end{array}$ & $\mathrm{N}$ & $\begin{array}{l}\text { Tertiary, } \\
\text { Industry }\end{array}$ & $\begin{array}{l}\text { Obligation Financial } \\
\text { Scheme }\end{array}$ \\
\hline Firm Plan 4.0 & $\mathrm{~N}$ & $\begin{array}{l}\text { Tertiary, } \\
\text { Industry }\end{array}$ & Alternative Fiscal \\
\hline $\begin{array}{l}\text { Cohesion } \\
\text { Policy }\end{array}$ & $\mathrm{N}, \mathrm{R}, \mathrm{L}$ & $\begin{array}{l}\text { Residential, } \\
\text { Tertiary, } \\
\text { Industry }\end{array}$ & Alternative Financial \\
\hline PEAR & $\mathrm{R}$ & $\begin{array}{c}\text { Residential, } \\
\text { Tertiary, } \\
\text { Industry }\end{array}$ & AlternativeRegulatory \\
\hline $\begin{array}{c}\text { Covenant of } \\
\text { Mayors }\end{array}$ & $\mathrm{L}$ & $\begin{array}{l}\text { Residential, } \\
\text { Tertiary, } \\
\text { Industry }\end{array}$ & Alternative Voluntary \\
\hline
\end{tabular}

\section{THEORETICAL FRAMEWORK}

AND METHODOLOGY

The approach used in this study is based on the stochastic production frontier model to estimate the frontier energy demand function for the building sector at regional level (Energy Efficiency studies at regional level based on SFA have been carried out by Otsuka and Goto [3]).

Moreover, econometric specifications of the model give the possibility to analyse the impact of the energy efficiency policy instruments examined at regional level. The analysis is based on the model introduced by Aigner (Aigner, Lovell and Schmidt [4] have used the stochastic frontier function in production theory to measure econometrically the economic performance of production processes at the firm level.) et al. (1976):

$$
y_{i}=f\left(x_{i}, \beta\right)+\varepsilon_{i}, i=1, \ldots \ldots, N, \operatorname{con}_{i} \leq 0
$$




$$
\varepsilon_{\mathrm{i}}=\mathrm{v}_{\mathrm{i}},+\mathrm{u}_{\mathrm{i}, \mathrm{i}}=1, \ldots \ldots, \mathrm{N}
$$

The author specified the variable $y_{i}$ as the maximum output obtainable from xi, a vector of (non-stochastic) inputs, and $\beta$ as an unknown parameter vector to be estimated.

The authors specified an error term (2) consisting of two independent parts: a stochastic error $\left(\mathrm{v}_{\mathrm{it}}\right)$, capturing the effect of noise, and a one-sided non-negative disturbance capturing the effect of inefficiency $\left(u_{i t}\right)$.

The component of the error vi represents a symmetrical disturbance, the vectors $\left\{\mathrm{v}_{\mathrm{i}}\right\}$ are independent and symmetrically distributed $\mathrm{N}\left(0, \sigma \mathrm{v}^{2}\right)$. The component $\left\{\mathrm{u}_{\mathrm{i}}\right\}$ is distributed independently of vi, satisfies the condition for which $\mathrm{u}_{\mathrm{i}} \leq 0$. and follows a truncated distribution $\mathrm{N}^{+}\left(0, \sigma \mathrm{u}^{2}\right)$.

The non-positive sign of the $u_{i}$ component implies that the output of each firm production is below or on the stochastic frontier. The $\mathrm{u}_{\mathrm{i}}$ component collects the effects due to factors directly controlled by the firms (such as the technology), which allow their different positioning in space and time on the frontier. The random disturbance factor $\left(\mathrm{v}_{\mathrm{i}}\right)$ can be the result of external and unpredictable events, due for example to climate, topography, machine performance, etc. The Stochastic Frontier approach, previously adopted by Aigner et al. [5] to measure the economic performance of production process, was applied by Filippini et al. [1, 2, 6] (First the stochastic frontier model has been employed by Filippini et al. [1] to estimate in the period 1978-2006 the minimum level of energy needed to produce the energy services of 29 OECD countries, second it has been employed by the author (2012) to estimate in the period 1995-2006 the level of energy efficiency in the residential sector for 48 US states, third it has been employed by the author (2014) to evaluate in the period 1996-2009 the effects of energy efficiency policies on energy demand residential sector for 27 EU Member States.) to estimate the level of energy efficiency of household consumption in the residential sector.

Filippini et al. refer to the "household production" theory [7] which considers the residential energy demand as a derived demand. In this model, households are considered as firms that produce goods and services not available on the market: i.e. heating their home, cooking a meal, hot water, etc. The production by families of these goods and services could be obtained through the efficient use of the production factors (inputs), such as: energy, available time, accumulated knowledge and capital.

Heating systems, cooling systems, house thermal insulation, devices for monitoring energy consumption are some examples of the capital could be employed in the household production process. In this scenario it can be understood technology plays a key role in the production process, improvements in technology could reduce the energy consumption necessary for the realization of these goods and services.

This model innovates with respect to previous studies, in which energy intensity, defined as the ratio of energy consumption to GDP, is used as a proxy of energy efficiency. Energy Intensity [8-14] fails to isolate the effects generated by the level of energy efficiency from those attributable to structural changes in the economy. The stochastic frontier model, on the other hand, using parametric models allows to identify the effects on demand due to the level of energy efficiency. In line with Filippini et al. [1, 2, 6] and based on the availability of the data, we have specified in this paper for the period $2010-2017(\mathrm{t}=2010-2017)$ the aggregate regional energy demand function for the civil sector of the 20 Italian regions $(i=1-20)$ :

$$
\mathrm{ED}_{\mathrm{it}}=\mathrm{E}\left(\begin{array}{l}
\mathrm{PE}_{\mathrm{it}} ; \mathrm{PG}_{\mathrm{it}} ; \mathrm{YD}_{\mathrm{it}} ; \mathrm{POP}_{\mathrm{it}} ; \\
\mathrm{HDD}_{\mathrm{it}} ; \mathrm{CDD}_{\mathrm{it}} ; \mathrm{SU}_{\mathrm{it}} ; \mathrm{D}_{\mathrm{t}} ; \mathrm{EF}_{\mathrm{it}}
\end{array}\right)
$$

The dependent variable $\mathrm{ED}_{\mathrm{it}}$ represents the final energy consumption in the civil sector, $\mathrm{PE}_{\mathrm{it}}$ the price of electricity, $\mathrm{PG}_{\mathrm{it}}$ the price of natural gas, $\mathrm{YD}_{\mathrm{it}}$ the disposable income per inhabitant, $\mathrm{POP}_{\mathrm{it}}$ the regional population, $\mathrm{SU}_{\mathrm{it}}$ the average surface area per occupant of the dwellings, $\mathrm{HDD}_{\text {it }}$ and $\mathrm{CDD}_{\mathrm{it}}$, respectively, the winter heating degree days and the summer cooling degree days.

The equation estimated in our study is the logarithmic transformation of (3):

$$
\begin{aligned}
& \mathrm{ed}_{\mathrm{it}}=\mathrm{a}+\mathrm{b}_{1} \mathrm{pe}_{\mathrm{it}}+\mathrm{b}_{2} \mathrm{pg}_{\mathrm{it}}+\mathrm{b}_{3} \mathrm{y}_{\mathrm{it}}+\mathrm{b}_{4} \text { pop }_{\mathrm{it}} \\
& +b_{5} h_{d d}+b_{6} c d d_{i t}+\$ \$ b_{7} s u_{i t}+b_{t} t+v_{i t}+u_{i t}
\end{aligned}
$$

where, $\mathrm{v}_{\mathrm{it}} \sim$ iid $\mathrm{N}\left(0, \sigma^{2}{ }_{\mathrm{v}}\right)$ e $\mathrm{u}_{\mathrm{it}} \sim \mathrm{N}^{+}\left(\mathrm{b}_{\mathrm{z}} \mathrm{z}_{\mathrm{it}}, \sigma^{2}{ }_{\mathrm{u}}\right)$. The error consists of two independent components: vit, the random disturbance component and $\mathrm{u}_{\mathrm{it}}$, the component that captures the effect of energy inefficiency $\left(\mathrm{EF}_{\mathrm{it}}\right)$.

This approach is in line with Battese and Coelli [15] (BC95 hereafter) that defined a stochastic frontier production function for panel data on firms, in which the non-negative technical inefficiency effects $\left(\mathrm{u}_{\mathrm{it}}\right)$ are assumed to be a function of firmspecific variables and time. The authors assumed the inefficiency effects to be independently distributed as truncations of normal distributions with constant variance, but with means which are a linear function of observable variables. (In Bottese and Coelli [15] the stochastic frontier model in terms of the original production value is explained by:

$$
\left.\mathrm{y}_{\text {it }}=\mathrm{f}\left(\mathrm{x}_{\mathrm{it}} \beta+\mathrm{v}_{\text {it }}-\mathrm{u}_{\mathrm{it}}\right) \mathrm{i}=1, \ldots \ldots, \mathrm{N}\right)
$$

$\mathrm{Y}_{\text {it }}$ denotes the production at the $\mathrm{t}$-th observation $(\mathrm{t}=1,2 \ldots$. $\mathrm{T})$ for the $\mathrm{i}$-th firm $(\mathrm{i}=1,2 \ldots, \mathrm{N})$; xit is a $(1 \mathrm{x} \mathrm{k})$ vector of values of known functions of inputs of production and other explanatory variables associated with the $\mathrm{i}$-th firm at the $\mathrm{t}$-th observation; $\beta$ is a ( $\mathrm{kx} 1)$ vector of unknown parameters to be estimated; the vit are assumed to be iid $\mathrm{N}\left(0, \sigma^{2} \mathrm{v}\right)$ random errors, independently distributed of the uit; the uit are nonnegative random variables, associated with technical inefficiency of production, which are assumed to be independently distributed, such that uit is obtained by truncation (at zero) of the normal distribution with mean, zit $\delta$, and variance, $\sigma^{2}$; zit is a $(1 \mathrm{x} \mathrm{m})$ vector of explanatory variables associated with technical inefficiency of production of firms over time; and $\delta$ is an ( $\mathrm{m} \times 1)$ vector of unknown coefficients.

The technical inefficiency effect, uit could be specified in equation:

$\mathrm{u}_{\mathrm{it}}=\mathrm{z}_{\mathrm{it}} \delta+\mathrm{W}_{\mathrm{it}}(2)$, where the random variable, Wit, is defined by the truncation of the normal distribution with zero mean and variance, $\sigma 2$, such that the point of truncation is $\mathrm{z}_{\mathrm{it}} \delta$, i.e., $\mathrm{W}_{\mathrm{it}}>-\mathrm{z}_{\mathrm{it}} \delta$.)

Filippini et al. [2] following BC95 model considered the techincal part of the error term $\left(\mathrm{u}_{\mathrm{it}}\right)$ as a one-sided nonnegative disturbance capturing the effect of inefficiency, as an indicator of the inefficient use of energy.

In this paper as in Filippini et al. [2] the inefficiency term $u_{i t}$ in Eq. (4) is modified to have a systematic component associated with a vector of policy measures (zit) and a random 
component $\left(\mathrm{e}_{\mathrm{it}}\right)$ :

$$
u_{i t}=b_{z} z_{i t}+e_{i t}
$$

The energy efficiency policies considered within the control variable $\mathrm{z}$ can be of different nature: fiscal, voluntary, regulatory, as already specified in Table 1 . In the econometric model analysed the energy efficiency policy variables have been represented by the indicators summarized in Table 2 . Policy instruments efficacy in promoting energy efficiency have been analysed in several studies [16].

Table 2. Energy Efficiency policy indicators control variables

\section{Name, Description and Nature}

$$
\mathrm{f}_{\mathrm{iS}_{\mathrm{it}}}=\frac{\text { Exp }_{\mathrm{E}} \text { cobonus }_{\mathrm{it}}}{\sum \text { Exp }_{E} \text { cobonus }_{\mathrm{it}}}
$$

Fis is the indicator of the fiscal policy measure represented by the

Ecobonus. It is obtained from the expenses incurred for energy requalification interventions by accessing the Ecobonus mechanism

(Expenditure_Ecobonus) for the i-th region at time $t$ on the total energy requalification costs in year $t$ considered by accessing the Ecobonus mechanism.

$$
\begin{aligned}
& \text { Nature: Fiscal } \\
& \text { fis }_{\mathrm{S}} \text { ct }_{\text {it }}=\frac{\text { Exp }_{\mathrm{E}} \text { cobonus }_{\mathrm{T}} \text { hermal }_{\mathrm{A}} \text { ccount }_{\mathrm{it}}}{\sum \text { Exp }_{\mathrm{E}} \text { cobonus }_{T} \text { hermal }_{A} \text { ccount }_{\mathrm{it}}}
\end{aligned}
$$

Fis_ct is the indicator of fiscal policy measures represented by the Ecobonus and the Thermal Account. It is obtained from the expenses incurred for interventions for the $\mathrm{i}$-th region by accessing the Ecobonus or Thermal Account mechanisms

(Expenditure_Ecobonus_ContoTermico) on the total energy requalification costs in year $t$ considered by accessing one of the two financing loans.

Nature: Financial

$$
\operatorname{sind}_{i t}=\frac{\text { pops }_{\mathrm{s}} \text { in }_{\mathrm{it}}}{\text { pop }_{i t}}
$$

Sind is the indicator relating to the voluntary policy measure represented by adherence to the Covenant of Mayors. It is obtained from the sum of the population of the municipalities of the $i$-th region that have joined the Covenant of Mayors (pop_sind) in relation to the total regional population (pop) in reference to the year t considered.

$$
\begin{aligned}
& \text { Nature: Voluntary } \\
& \text { prgee }_{i t}=\frac{\operatorname{proj}_{\mathrm{e}} \mathrm{ff}_{\mathrm{e}} \mathrm{n}_{\mathrm{it}}}{\sum_{\mathrm{t}} \operatorname{proj}_{e} f f_{e} n_{i t}}
\end{aligned}
$$

Prgee is the indicator relating to the participation of each region in energy redevelopment projects. It is obtained from the value (in euros) of energy efficiency projects (prog_eff_en) financed through

Structural Funds of the i-th region on the total value of energy efficiency projects financed in Italy through the use of Structural Funds for the year $t$.

Nature: Financial

Dummy PEAR is the indicator relating to the participation of each region in the Regional Environmental Energy Plan, it is a dummy that indicates whether an i-th region has joined the Regional Energy and Environmental Plan and the year $t$ of membership. If the PEAR dummy takes value 1 it means that the plan is present, therefore it

has been adopted by Region, if it takes value 0 it means that the

Region has not yet joined the PEAR. PEAR adhesions that are

considered in line with the requirements in terms of energy efficiency are those carried out starting from 2012, the year of entry into force of the new Energy Efficiency Directive. Nature: Regulatory

In this paper we focus on the effects of energy policy measures on the level of energy efficiency at regional level.
We have identified the panel data model proposed by Battese and Coelli for the estimation of Eq. (4) through the stochastic frontier model (SFM). Following Filippini et al. [2] BC95 panel data model it is a suitable approach because allow to estimate the level of energy efficiency to vary over time and to depend on a set of variables (i.e. the presence of subsidies, fiscal deduction for building renovation expenses, energy efficiency voluntary measures adoption, utilization of European Funds available for energy efficiency).

The estimated energy-efficiency level could be identified in terms of efficiency score:

$$
\mathrm{EF}_{\mathrm{it}}=\mathrm{EF}_{\mathrm{it}} / \mathrm{E}_{\mathrm{it}} \exp \left(-\mu^{\mathrm{it}}\right) \$
$$

where, EDit is the observed final energy demand and EDFit is the respective frontier demand of the $i$ th italian region in time t.

Our theoretical framework is also based on the Environmental Kuznets Curve (The the environmental Kuznets curve (EKC) was coined by U. Panayotou [17] and the relatioship between the evolution of the distribution of per capita income and the trend of environmental pressure was confirmed by the independent empirical studies by Grossman and Krueger (1991), Shafik and Bandyopadhyay (1992) and Panayotou (1993).) (EKC). EKC shows an inverted U relationship, as in the Kuznets [18] (Kuznets [18] observed in the first stage of a country development, as per capita income increases, the level of inequality within the population increases, as those who earn a higher per capita income tend to invest a greater share of it, increasing the gap with the poorer population. The point that leads to a progressive decrease in the level of inequality is due to the introduction by the government taxation mechanisms penalizing the part of population with greater availability of capital and income.) original curve, between the evolution of the distribution of per capita income and the trend of environmental pressure. The assumptions underlying this trend can be traced back to the fact that in the early stages of the development of an economic system, the population does not have adequate awareness of environmental issues and the negative effects that could arise from uncontrolled economic growth. Such growth in per capita income could lead to a resource wasting rate higher than its regeneration rate and to a significant increase in the level of pollution.

The gradual increase in awareness of environmental issues, even in the presence of sustained levels of economic growth, instead favors the definition of specific environmental laws and regulations, greater investments in research and development in favor of new, more efficient and less polluted technologies and the creation of greater civitenship within the community to which they belong.

The specification of the cubic standard model of the EKC is expressed in the following formula:

$$
\mathrm{E}_{\mathrm{it}}=\mathrm{A}_{\mathrm{i}}+\beta_{1} \mathrm{Y}_{\mathrm{it}}+\beta_{2} \mathrm{Y}_{\mathrm{it}}^{2}+\beta_{3} \mathrm{Y}_{\mathrm{it}}^{3}+Z_{\mathrm{it}}+\mathrm{e}_{\mathrm{it}}
$$

where, $\mathrm{E}$ is the indicator of per capita energy consumption expressed in logarithmic form, $\mathrm{Y}$ is per capita income, also expressed in logarithmic form, A is the set of time variables, $\mathrm{Z}$ represents a series of control variables that could impact energy consumption, e represents a random error component.

In the Energy Environmental Kuznets Curve the energy consumption is a key indicator for the environmental pressure. 
Luzzati et al. [19-24] have already analyzed and confermed in their work a strong relationship between income and energy consumption which shows an inverted $U$ relationship.

In Romero et al. [20] it has been analysed whether the municipalities of Andalusia that have joined the "Covenant of Mayors" have reduced the level of energy consumption and climate-altering emissions. Consumption has also been divided within the civil sector between the Public Administration and residential buildings. Control variables $\mathrm{Z}$ were defined in Romero et al. [20], as follows:

$$
Z_{i t}=\beta_{4} \mathrm{CM}_{i t}+\beta_{5} A D_{i t}+\beta_{6} S E_{i t}
$$

where, CM (Covenant of Mayors) is a dummy which takes value 1 if the municipality has joined or 0 if not, the variables $\mathrm{D}$ and SE indicate, respectively, the population density and the area of the municipality. The existence of an inverted $U$ relationship implies that for the relations between energy consumption and income $\beta 1>0, \beta 2<0$ and $\beta 3 \leq 0$. The results of the econometric estimates reveal differences in consumption between the Andalusian municipalities that have joined the Covenant of Mayors compared to those that have not joined.

Following the approach introduced by Romero et al. and based on the availibility of data we have specified the relationship between income and energy consumption in the period $2010-2017(t=2010-2017)$ for the civil sector of the 20 Italian regions $(i=1-20)$ :

$$
\mathrm{E}_{\mathrm{it}}=\mathrm{E}\left(\underline{\mathrm{YD}}_{\mathrm{it}} ; \underline{\mathrm{YD}}^{2} \mathrm{it} ; \underline{\mathrm{YD}}^{3} \mathrm{it} ; \mathrm{Z}_{\mathrm{it} ;} \mathrm{DPOP}_{\mathrm{it}} \mathrm{S}_{-} \mathrm{KM}^{2} \mathrm{it}\right)
$$

The dependent variable Eit represents the final energy consumption in the civil sector, $\mathrm{YD}_{\mathrm{it}}$ geometrical mean of the disposable income per inhabitant, $\mathrm{DPOP}_{\mathrm{it}}$; the population density and $\mathrm{S}_{-} \mathrm{KM}^{2}{ }_{\text {it }}$ the regional surface.

\section{DATASET CHARACTERISTICS}

The database we have built for the econometric estimates is obtained with the contribution of various sources: Regional Energy Balances prepared by ENEA, Energy and gas price data managed by ARERA, Ecobonus incentives data managed by ENEA, Thermal Account data managed by GSE, Covenant of Mayors data for the municipalities adhering to the agreement and others. This database allow us to evaluate the effects of different energy efficiency policies in the civil sector at a disaggregated level for the twenty Italian regions $(i=1, \ldots$, $20)$ in the eight years observed $(t=2010, \ldots \ldots, 2017)$.

The dependent variable Eit represents the final energy consumption in the civil sector, measured in ktoe (kilo toe, tons of oil equivalent), as reported in the Regional Energy Balance Sheet (BER) prepared by ENEA.

The BER (From a practical point of view, BER is presented in a series of sections, including those of final energy consumption, disaggregated into industry, transport and other sectors. The detail of the energy demand of the civil sector (Eit) for each Italian region is contained in the "other sectors" section.) consists of an energy accounting model that describes the preparation of the availability (supply) and uses (demand) of energy sources that takes place in a given period of time (year) in the observed economic system (region).

$\mathrm{PE}_{\mathrm{it}}$ variable is an elaboration based on the Italian Regulatory Authority for Energy, Networks and the Environment (ARERA) dataset. This variable represents the price of electricity for the enhanced protection service, expressed in euros $(€)$, calculated on the basis of annual regional consumption expressed in kilowatt hours (kWh).

$\mathrm{PG}_{\mathrm{it}}$ (Since the Sardinia region has not yet been methanized, this field is not valued.) variable is an elaboration on ARERA dataset and represents the price of natural gas for the protection service, expressed in euros $(€)$ calculated on the basis of regional consumption expressed in standard cubic meter (smc).

$\mathrm{YD}_{\mathrm{it}}$ is the disposable income per inhabitant at purchasing power parity (Eurostat), $\mathrm{YD}_{\mathrm{it}}$ the geometric mean of disposable income per inhabitant at purchasing power parity, $\mathrm{POP}_{i t}$ the population resulting from the ISTAT demographic balance sheet for the years analysed, $\mathrm{SU}_{\mathrm{it}}$ the average surface area per occupant of the dwellings expressed in square meters referring to resident persons from ISTAT website in the section dedicated to the "Permanent Census of Populations and Housing".

In order to verify the impact of climatic conditions, two variables were considered, $\mathrm{HDD}_{\mathrm{it}}$ and $\mathrm{CDD}_{\mathrm{it}}$, expressed in $\mathrm{C}^{\circ}$ which represent, respectively, the winter heating degree days and the summer cooling degree days. They are defined as the difference between a comfort temperature, called basetemperature (with respect to which the energy demand is minimal) and the outside daily mean temperature. Conventionally the degree days are computed at annual scale (HDD and CDD respectively), by adding such differences for every day of the year. The datasets of the HDDs and CDDs for the period under analysis are available on the Joint Research Centre (JRC) website for the twenty Italian regions. DPOP is the population density obtained from the ratio between regional population and regional surface (S_KM2), the open data of the regional surface are available in the ISTAT website in the publication dedicated to the Territory. Descriptive statistics of the variables included in the model are presented in Table 3.

Table 3. Descriptive statistics

\begin{tabular}{cccccc}
\hline $\begin{array}{l}\text { Var (The variables } \\
\text { reported in Table 3 } \\
\text { are in logarithms.) }\end{array}$ & Mean & $\begin{array}{c}\text { Stand. } \\
\text { Dev. }\end{array}$ & Min. & Max. \\
\hline Ed & 160 & 7.32639 & 1.042312 & 5.169216 & 9.374322 \\
Hdd & 160 & 7.516664 & .3836878 & 6.790052 & 8.495898 \\
Cdd & 160 & 4.974862 & 1.373163 & -1.966113 & 6.218242 \\
Yd & 160 & 9.68641 & .2005476 & 9.332558 & 9.971147 \\
Pop & 160 & 14.48442 & 1.071473 & 11.74564 & 16.12172 \\
Pe & 160 & 5.611317 & .1813785 & 5.059175 & 5.985239 \\
Pg & 152 & 6.060195 & .2034028 & 5.608993 & 6.50895 \\
Su & 160 & 3.710068 & .0705386 & 3.519869 & 3.826901 \\
Sind & 135 & -1.564918 & 1.493171 & -6.50229 & -.0022024 \\
Fis & 160 & -3.651988 & 1.19608 & -6.130224 & -1.334492 \\
Fisc & 160 & -3.647277 & 1.191134 & -6.063481 & -1.334492 \\
Prgee & 143 & 15.62117 & 1.661246 & 9.893381 & 19.31571 \\
Yd & 96 & 7.726168 & .63854 & 5.712558 & 8.575961 \\
pesr & 160 & .15625 & .3642322 & 0 & 1 \\
km 2 & 160 & 9.471239 & 5.994711 & 8.089759 & 10.15938 \\
dpop & 160 & 5.01318 & .6494802 & 3.65588 & 6.062331 \\
\hline & & & & & \\
\hline
\end{tabular}

\section{RESULTS}

\subsection{Estimated energy demand model for the building sector}

The BC95 SFA model estimation results (Table 4) of the relationship (4) between the building energy sector demand 
and the other variables, that include as usual time dummies (btt), expressed in logarithms form (10) prove to have the expected signs and are generally statistically significant:

$$
\begin{aligned}
& \mathrm{e}_{\mathrm{it}}=\alpha+\mathrm{b}_{1} \mathrm{pe}_{\mathrm{it}}+\mathrm{b}_{2} \mathrm{pg}_{\mathrm{it}}+\mathrm{b}_{3} \mathrm{yd}_{\mathrm{it}}+\mathrm{b}_{4} \mathrm{pop}_{\mathrm{it}}+\mathrm{b}_{5} \mathrm{hdd}_{\mathrm{it}} \\
& +\mathrm{b}_{6} \mathrm{cdd}_{\mathrm{it}}+\mathrm{b}_{7} \mathrm{su}_{\mathrm{it}}+\mathrm{b}_{8} \mathrm{Z}_{\mathrm{it}}+\mathrm{b}_{\mathrm{t}} \mathrm{t}+\mathrm{v}_{\mathrm{it}}+\mathrm{u}_{\mathrm{it}},
\end{aligned}
$$

where, $\mathrm{i}$ is the th Italian region and $\mathrm{t}$ is the the and we assume that $\mathrm{v}_{\mathrm{it}} \sim$ iid $\mathrm{N}\left(0, \sigma^{2}{ }_{\mathrm{v}}\right)$ e uit $\sim \mathrm{N}^{+}\left(\mathrm{b}_{\mathrm{z}} \mathrm{Z}_{\mathrm{it}}, \sigma_{\mathrm{u}}^{2}\right)$.

Since energy consumption and the regressors relating to the variables examined are in logarithms the estimated coefficients are directly interpretable as demand elasticities.

From the estimated coefficients it emerges that as the price electricity decreases (pe) energy consumption in the building sector (ed) increases, in line with the decarbonisation objectives of the INECP, for example by replacing gas boilers with heat pumps, it is also possible to provide summer cooling, which is especially important in Southern Italy. Consumption does not seem to be affected by changes in gas prices (pg), because is necessary a minimum energy requirements to heat homes (the variable pg is not elastic to changes in gas prices). From the estimates of the coefficients it can be deduced, in line with expectations, that an increase in population (pop), in the average area occupied (su), in disposable income (yd), in heating (hdd) and cooling degrees days (cdd) determines an increase in energy demand in the building sector (ed).

The estimates confirms the effectiveness of policy instruments examined such as Ecobonus (fis) and the Thermal Account (fis_ct) in reducing energy consumption in the building sector.

There is also some evidence that Covenant of Mayors (sind) contribute to the improved technical efficiency.

Although some results of the estimates show the effectiveness of the Covenant of Mayors initiative on reducing consumption, this level of effectiveness is not always confirmed. The partial effectiveness in reducing consumption can be attributed to the nature of the Covenant of Mayors, which is on a voluntary basis. The adherence by the municipalities to the Covenant should lead to a series of actions within two years of signing (SECAP, inventory of emissions, periodic monitoring, etc.) that are not always implemented.

In fact, in the ten years of life of the initiative, despite Italy is the country with the highest number of adhesions, the participation of the municipalities in the initiative was limited in most cases to a "formal adhesion".

The other policy instruments examined such as Energy Efficiency Projects financed by Cohesion Funds (prgee) and Environmental Energy Regional Plans (pear) do not seem to have an influence on reducing energy consumption in the building sector. As can be seen from Table 4, the fis, fis_ct and sind indicators are significant and effective in reducing regional energy consumption in the building sector (ed).

The introduction of a $\mathrm{t}-1$ time lag in the SFA model (11), that include as usual time dummies (btt), is justified by the delayed effect of the policies promoting energy efficiency analysed in the model:

$$
\begin{aligned}
& \mathrm{ed}_{\mathrm{it}}=\alpha+\mathrm{b}_{1} \mathrm{pe}_{\mathrm{it}-1}+\mathrm{b}_{2} \mathrm{pg}_{\mathrm{it}-1}+\mathrm{b}_{3} \mathrm{yd}_{\mathrm{it}-1}+\mathrm{b}_{4} \text { pop }_{\mathrm{it}-1}+\mathrm{b}_{5} \mathrm{hdd}_{\mathrm{it}-1} \\
& +\mathrm{b}_{6} \mathrm{cdd}_{\mathrm{it}-1}+\mathrm{b}_{7} \mathrm{su}_{\mathrm{it}-1}+\mathrm{b}_{8} \mathrm{Z}_{\mathrm{it}-1}+\mathrm{b}_{\mathrm{t}} \mathrm{t}+\mathrm{z}_{\mathrm{it}-1}+\mathrm{v}_{\mathrm{it}-1}+\mathrm{u}_{\mathrm{it}-1},
\end{aligned}
$$

where, $\mathrm{i}$ is the th Italian region and $\mathrm{t}$ is the th period and we assume that $\mathrm{v}_{\mathrm{it}} \sim$ iid $\mathrm{N}\left(0, \sigma^{2}{ }_{\mathrm{v}}\right)$ e $\mathrm{u}_{\mathrm{it}} \sim \mathrm{N}+\left(\mathrm{b}_{\mathrm{z}} \mathrm{z}_{\mathrm{it}}, \sigma^{2}{ }_{\mathrm{u}}\right)$.
The building renovation investment produce their effect generally one year later than when the expenses were incurred.

The estimates by introducing a t-1 delay (Table 5) for all variables confirm the effectiveness of the fiscal and economic incentives (fis, fis_ct).

The estimates were repeated by evaluating in the SFA model the joint effect of the policy variables fis_ct, sind, prgee, pear:

$$
\begin{aligned}
& e d_{i t}=\alpha+b_{1} p e_{i t}+b_{2} p_{i t}+b_{3} y d_{i t}+b_{4} \text { pop }_{i t}+b_{5} h d d_{i t}+b_{6} c d d_{i t}+b_{7} s_{i t} \\
& +b_{8} f_{1 t} s_{t} t_{t i}+b_{9} \text { sind }_{i t}+b_{10} \text { prgee }_{i t}+b_{11} \text { pear }_{i t}+b_{t} t+v_{i t}+u_{i t}
\end{aligned}
$$

\begin{tabular}{|c|c|c|c|c|}
\hline & = fis_ct & $\mathrm{z}=$ sind & $=$ prgee & $\mathrm{z}=$ pear \\
\hline \multirow[t]{2}{*}{$\mathrm{Pe}$} & $-.1744993^{* * *}$ & $-.1912166^{* * *}$ & & \\
\hline & & & & \\
\hline \multirow[t]{2}{*}{$\mathrm{Pg}$} & & & & \\
\hline & & & & \\
\hline $\mathrm{Yd}$ & & & & **** \\
\hline Pop & $\begin{array}{r}.88729 \\
(.0128\end{array}$ & $\begin{array}{l}.911 \\
(.01\end{array}$ & $\begin{array}{r}.976 \\
(.0\end{array}$ & *** \\
\hline $\mathrm{Su}$ & & & & $\begin{array}{l}7 * * * \\
932)\end{array}$ \\
\hline Hdd & & & & \\
\hline \multirow[t]{2}{*}{ Cdd } & 5) & $\begin{array}{l}.0553406 * * * \\
(.0141575)\end{array}$ & $\begin{array}{l}-.001575 \\
.019279\end{array}$ & $\begin{array}{l}5 \\
8)\end{array}$ \\
\hline & \multicolumn{4}{|c|}{ Variable in the one sided error } \\
\hline \multirow[t]{2}{*}{$\mathrm{Z}$} & $\begin{array}{c}-.1710679 * * \\
(.0622575)\end{array}$ & $\begin{array}{c}-.3526583 * * \\
(.1537179)\end{array}$ & $\begin{array}{l}-.4072093 \\
(.2963355)\end{array}$ & $\begin{array}{l}359 \\
72)\end{array}$ \\
\hline & \multicolumn{4}{|c|}{ Variance Parameters } \\
\hline sigm & $.294125^{* *}$ & $.2821993 * *$ & $.7279158^{* *}$ & \\
\hline a_u & & & & \\
\hline $\begin{array}{c}\text { Lam } \\
\text { da }\end{array}$ & $\begin{array}{r}12.8475 \\
(.126\end{array}$ & $\begin{array}{r}98.756 \\
(.0485\end{array}$ & & $\begin{array}{r}12.81 \\
(.173\end{array}$ \\
\hline Obs. & 152 & 152 & 128 & 152 \\
\hline \multirow[t]{4}{*}{$\begin{array}{l}\text { Info. } \\
\text { Stat. }\end{array}$} & $\begin{array}{c}\text { Prob }>\text { chi } 2= \\
0.0000\end{array}$ & $\begin{array}{c}\text { Prob }>\text { chi } 2= \\
0.0000\end{array}$ & $\begin{array}{c}\text { Prob }>\text { chi } 2= \\
0.0000\end{array}$ & $\begin{array}{c}\text { Prob }>\text { chi } 2= \\
0.0000\end{array}$ \\
\hline & $\begin{array}{l}\text { Log likelihood } \\
=144.9104\end{array}$ & $\begin{array}{l}\text { Log likelihood } \\
=142.6992\end{array}$ & $\begin{array}{l}\text { Log likelihood } \\
=116.8455\end{array}$ & $\begin{array}{l}\text { Log likelihood } \\
=134.0750\end{array}$ \\
\hline & Wald chi2(15) & Wald chi2(15) & Wald chi2(15) & Wald chi2(15) \\
\hline & $=1.46 \mathrm{e}+10$ & $=1.32 \mathrm{e}+10$ & $=14075.17$ & $=29512.73$ \\
\hline
\end{tabular}

where, $\mathrm{i}$ is the th Italian region and $\mathrm{t}$ is the th period and we

\begin{tabular}{|c|c|c|}
\hline Var. & BC95, $\mathrm{z}=$ fis & BC95, $\mathrm{z}=$ fis_ct \\
\hline 11.pe & $-.2114728 * * *(.0570794)$ & $-.2084465 * * *(.056924)$ \\
\hline 11.pg & $.4427168 * * *(.1245042)$ & $.4372655^{* * *}(.1143704)$ \\
\hline 11.yd & $1.006848 * * *(.1315006)$ & $.985603 * * *(.1126335)$ \\
\hline 11.pop & $.9391493 * * *(.0174912)$ & $.9357147 * * *(.0169606)$ \\
\hline $11 . \mathrm{su}$ & $.2325548(.2440616)$ & $.2444348(.2371826)$ \\
\hline 11.hdd & $.3675264 * * *(.0748506)$ & $.0419369 * *(.0163122)$ \\
\hline 11.cdd & $.0394121 * *(.0176122)$ & $.3637302 * * *(.0694519)$ \\
\hline \multicolumn{3}{|c|}{ Variable in the one sided error } \\
\hline $11 . \mathrm{z}$ & $-.3309931 * * *(.075085)$ & $-.2993487 * * *(.0653294)$ \\
\hline \multicolumn{3}{|c|}{ Variance parameters } \\
\hline Sigma_u & $.4472706^{* * *}(.0576757)$ & $.4122384 * * *(.0490501)$ \\
\hline Lamda & $27.18474 * * *(.0632917)$ & $22.26869 * * *(.0515975)$ \\
\hline \multicolumn{3}{|c|}{ Time Dummy: yes } \\
\hline Obs. & 133 & 133 \\
\hline \multirow[t]{2}{*}{ Info.Stat. } & Prob $>$ chi $2=0.0000 \log$ & Prob $>$ chi $2=0.0000 \mathrm{Log}$ \\
\hline & $\begin{array}{c}\text { likelihood }=119.3358 \text { Wald } \\
\operatorname{chi} 2(14)=41479.72\end{array}$ & $\begin{array}{l}\text { likelihood }=119.4192 \text { Wald } \\
\text { chi2 } 2(14)=40225.33\end{array}$ \\
\hline
\end{tabular}
assume that $\mathrm{v}_{\mathrm{it}} \sim$ iid $\mathrm{N}\left(0, \sigma_{\mathrm{v}}^{2}\right)$ e $\mathrm{u}_{\mathrm{it}} \sim \mathrm{N}+\left(\mathrm{b}_{\mathrm{z}} \mathrm{z}_{\mathrm{it}}, \sigma_{\mathrm{u}}^{2}\right)$.

Table 4. Estimated Energy demand for building sector

Table 5. Estimated Energy demand for building sector with a t-1 delay 
The results (Table 6) highlight the significance and the negative sign of fis_ct, sind and prgee so the estimates suggest a positive impact of the energy policy mix compared to the single policy.

These policies mix contributes to the reduction of energy consumption and to a greater value of technical efficiency thanks to greater energy efficiency investments. Probably this behaviour could be due to potential synergy between different policy instruments, i.e. the economic measure could be favoured by normative and voluntary measures.

Descriptive statistics of the level of energy efficiency are reported in Table 7 . The estimated average energy efficiency resulting from the BC95 model is $86.8 \%$ in the case control variable $\mathrm{z}$ is equal to fis_ct and is $87 \%$ in the case the control variable $\mathrm{z}$ is equal to fis.

Table 6. Estimated Energy demand for building sector with the joint effect of the control variables

\begin{tabular}{cc}
\hline Var. & BC95 \\
\hline pe & $-.1305818^{* * *}(.0162089)$ \\
pg & $.5848554^{* * *}(.0515237)$ \\
yd & $1.006771^{* * *}(.0464216)$ \\
pop & $.8929151^{* * *}(.0074237)$ \\
su & $-.3765358^{* *}(.1351003)$ \\
hdd & $.4226318 * * *(.0365021)$ \\
cdd & $.0499384 * * *(.0112912)$ \\
& Variable in the one sided error \\
fis_ct & $-3.019536 * *(1.097651)$ \\
sind & $-1.157722^{*}(.6199396)$ \\
prgee & $-1.840005 * *(.9390928)$ \\
pear & $-4.367681(4.889306)$ \\
& Variance parameter \\
Sigma_u & $1.380238^{* * *}(.1792289)$ \\
Lamda & $519.2838 * * *(.1790453)$ \\
Obs. & Time dummy: yes \\
Info. Stat. & Prob $>$ chi2 $=0.0000$ Log likelihood \\
& $=120.8323$ \\
& Wald chi2 $(15)=2.52 \mathrm{e}+10$ \\
\hline p-value $=0.10, * *$ p-value $=0.05, * * *$ p-value $=0.001$
\end{tabular}

Table 7. Technical Efficiency for Fiscal and Economic Incentive Policies (The analysis is carried out for the more effective energy efficiency policies studied in the econometric models analysed.)

\begin{tabular}{cccccc}
\hline Variable & Mean & St. Deviation & Min & Max & Cases \\
\hline EFBC95 & .87031 & .11011 & .61223 & .99806 & 152 \\
z = fis & & & & & \\
EFBC95 & .86833 & .11122 & .59708 & .99745 & 152 \\
z = fis_ct & & & & & \\
\hline
\end{tabular}

\subsection{Estimated energy demand model for the building sector with geographical and regional dummies}

The introduction of the geographical dummy $\left(b_{g} g\right)$ North, Centre and South (Table 8) in the estimated model, that include as usual time dummies $\left(\mathrm{bt}_{\mathrm{t}}\right)$ and geographical dummies $\left(b_{g} g\right)$, shows greater effectiveness of fis, fis_ct and sind for the areas of Northern Italy:

$$
\begin{aligned}
& \text { ed }_{\text {it }}=\alpha+b_{1} \text { pe }_{i t}+b_{2} \text { pg }_{i t}+b_{3} y_{i t}+b_{4} \text { pop }_{i t}+b_{5} \text { hdd }_{\text {it }} \\
& +b_{6} \text { cdd }_{i t}+b_{73} u_{i t}+b_{8} z i t+b_{t} t+b g+v_{i t}+u_{i t}
\end{aligned}
$$

where, $i$ is the th Italian region and $t$ is the th period and we assume that $\mathrm{v}_{\text {it }} \sim$ iid $\mathrm{N}\left(0, \sigma_{\mathrm{v}}^{2}\right)$ e $\mathrm{u}_{\mathrm{it}} \sim \mathrm{N}^{+}\left(\mathrm{b}_{\mathrm{z}} \mathrm{z}_{\mathrm{it}}, \sigma_{\mathrm{u}}^{2}\right)$. By introducing a t-1 delay for all the variables (Table 9) in the model, that include as usual time dummies $\left(\mathrm{bt}_{\mathrm{t}}\right)$ and

geographical dummies $\left(b_{\mathrm{g}} \mathrm{g}\right)$, the policy indicators fis and fis_ct are significant, of negative sign:

$$
\begin{aligned}
& \text { ed }_{\text {it }}=\alpha+b_{1} \text { pe }_{i t-1}+b_{2} \text { pg }_{i t-1}+b_{3} y_{\text {it }-1}+b_{4} \text { pop }_{i t-1}+b_{5} \text { hdd }_{i t-1} \\
& +b_{6} \text { cdd }_{i t-1}+b_{7} \text { su }_{i t-1}+b_{8} z_{i t-1}+b_{t} t+b_{g g}+v_{i t-1}+u_{i t-1}
\end{aligned}
$$

where, $\mathrm{i}$ is the th Italian region and $\mathrm{t}$ is the theriod and we assume that $\mathrm{v}_{\mathrm{it}} \sim \mathrm{iid} \mathrm{N}\left(0, \sigma^{2}{ }_{\mathrm{v}}\right)$ e $\mathrm{u}_{\mathrm{it}} \sim \mathrm{N}^{+}\left(\mathrm{b}_{\mathrm{z}} \mathrm{z}_{\mathrm{it}}, \sigma_{\mathrm{u}}^{2}\right)$. This tendency is confirmed by the data monitored annually (by ENEA), which show a greater concentration of investments in Northern Italy.

Table 8. Estimated Energy demand for building sector with the geographical dummy

\begin{tabular}{|c|c|c|c|c|}
\hline Var. & \multicolumn{2}{|c|}{ BC95, $z=$ fis } & \multicolumn{2}{|c|}{ BC95, $z=$ fis_ct } \\
\hline $1_{1}$.pe & -.0702169 & $(.1065016)$ & -.0758702 & $(.1065499)$ \\
\hline $1_{1} \cdot \mathrm{pg}$ & $.2772418 * * *$ & $(.0809954)$ & $.2763489 * * *$ & $(.0806282)$ \\
\hline $1_{1} \cdot y d$ & $1.043124 * * *$ & $(.1209253)$ & $1.048386^{* * * *}$ & $(.1194268)$ \\
\hline $1_{1}$.pop & $.9578194 * * *$ & $(.0199808)$ & $.9596841 * * *$ & $(.0202216)$ \\
\hline $1_{1}$ su & $.7575552 * * *$ & $(.1814364)$ & $.7558226^{* * * *}$ & $(.1789474)$ \\
\hline $1_{1}$.hdd & $.3492961 * * *$ & $(.0767362)$ & $.3542085 * * *$ & $(.0766082)$ \\
\hline $1_{1} \cdot$ cdd & .0051821 & $(.013802)$ & .0047911 & $(.0136552)$ \\
\hline \multicolumn{5}{|c|}{ Variable in the one sided error } \\
\hline $1_{1} \cdot \mathrm{z}$ & $-.4734342 * * *$ & $(.0955531)$ & $-.5662282 * * *$ & $(.1240197)$ \\
\hline \multicolumn{5}{|c|}{ Variance parameters for the compound error } \\
\hline Sigma_u & $.4944692 * * *$ & $(.0567995)$ & $.5533447 * * *$ & $(.065522)$ \\
\hline Lamda & $20.96999 * * *$ & $(.0604253)$ & $23.89932 * * *$ & $(.0693334)$ \\
\hline \multicolumn{5}{|c|}{ Time dummy: yes } \\
\hline Obs. & \multicolumn{2}{|c|}{133} & \multicolumn{2}{|c|}{133} \\
\hline Info. Stat. & $\begin{array}{r}\text { Prob }>\text { chi } 2= \\
\text { likelihood } \\
\text { Wald chi2 }(16\end{array}$ & $\begin{array}{rl} & 0.0000, \mathrm{Log} \\
1 & 31.2722 \\
= & 42766.65\end{array}$ & \multicolumn{2}{|c|}{$\begin{array}{c}\text { Prob }>\text { chi } 2=0.0000, \text { Log } \\
\text { likelihood }=131.1533 \text { Wald } \\
\text { chi2 } 2(16)=44172.10\end{array}$} \\
\hline
\end{tabular}

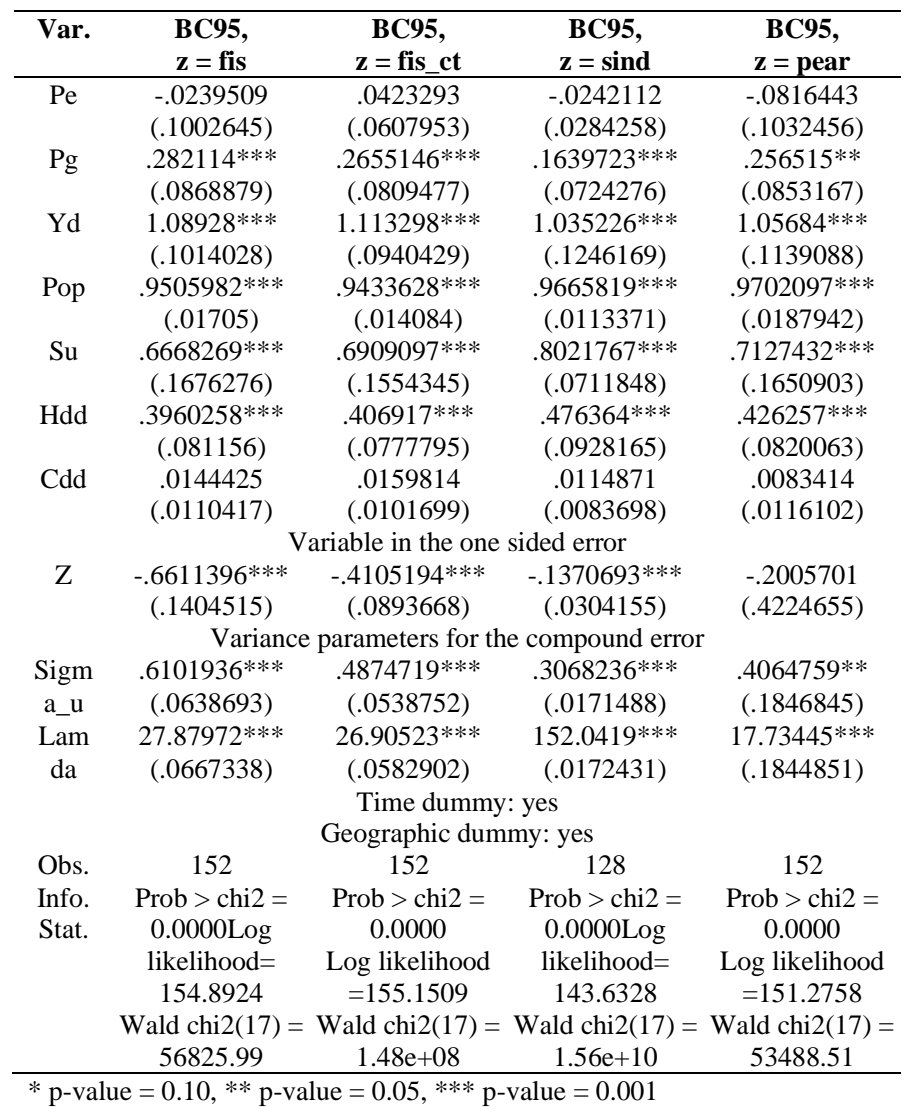

Table 9. Estimated Energy demand for building sector with geographical dummy introducing a t-1 delay 
Table 10. Estimated Energy demand for building sector with regional dummy

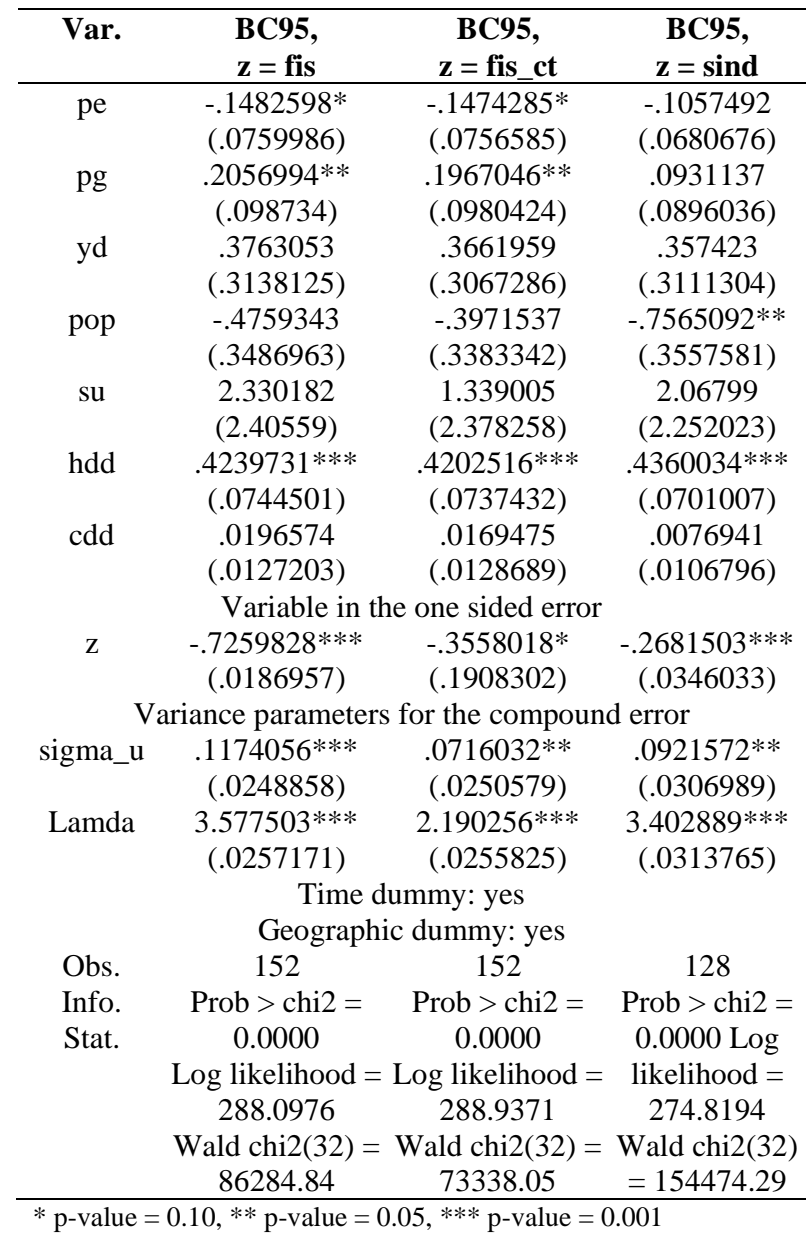

Table 11. Estimated Energy demand for building sector with regional dummy introducing a t-1 delay

\begin{tabular}{|c|c|c|}
\hline Var. & BC95, $z=$ fis & BC95, $\mathrm{z}=$ fis_ct \\
\hline 11.pe & $-.2054653 *(.1093347)$ & $-.2016653 *(.1092943)$ \\
\hline 11.pg & $-.2295514 * *(.0995279)$ & $-.2300785 * *(.0992409)$ \\
\hline 11.yd & $.3335378(.3087272)$ & $.3523648(.3088527)$ \\
\hline 11.pop & $-.5173436(.3834508)$ & $-.4756961(.3852395)$ \\
\hline $11 . \mathrm{su}$ & $4.100921 *(2.444049)$ & $4.400329 *(2.430491)$ \\
\hline L1.hdd & .1249987(.0791701) & $.1232163(.0791918)$ \\
\hline L1.cdd & $.0351069 * *(.0122924)$ & $.0350468(.0123233)$ \\
\hline \multicolumn{3}{|c|}{ Variable in the one sided error } \\
\hline $\mathrm{L} 1 . \mathrm{z}$ & $-1.16065 * * *(.1845509)$ & $-1.079057 * * *(.13521)$ \\
\hline \multicolumn{3}{|c|}{ Variance parameters for the compound error } \\
\hline Sigma_u & $.1563709 * *(.0785397)$ & $.147246 * *(.0705643)$ \\
\hline Lamda & $4.756713 * * *(.0802806)$ & $4.505683 * * *(.0723153)$ \\
\hline \multicolumn{3}{|c|}{$\begin{array}{l}\text { Time dummy: yes } \\
\text { Regional dummy: yes }\end{array}$} \\
\hline Oss. & 133 & 133 \\
\hline Info. Stat. & $\begin{array}{l}\text { Prob }>\text { chi } 2=0.0000 \text { Log } \\
\quad \text { likelihood }=260.0922 \\
\text { Wald chi2 }(31)=67277.21\end{array}$ & $\begin{array}{c}\text { Prob }>\text { chi } 2=0.0000 \text { Log } \\
\text { likelihood }=260.1589 \\
\text { Wald chi2 } 2(31)=68913.86\end{array}$ \\
\hline
\end{tabular}

The renovation interventions promoted with ECOBONUS and Thermal Account mechanisms are more effective in the North area of Italy because they are mainly dedicated to the reduction of heat requirements (i.e. replacement of doors and windows and the winter heating system). All the estimates, that include as usual time dummies $\left(b_{t}\right)$, have been repeated by introducing in the SFA model regional dummies $\left(b_{\mathrm{r}} \mathrm{r}\right)$ for each Italian region:

$$
\begin{aligned}
& \mathrm{ed}_{\mathrm{it}}=\alpha+\mathrm{b}_{1} \mathrm{pe}_{\mathrm{it}}+\mathrm{b}_{2} \mathrm{pg}_{\mathrm{it}}+\mathrm{b}_{3} \mathrm{yd}_{\mathrm{it}}+\mathrm{b}_{4} \text { pop }_{\mathrm{it}}+\mathrm{b}_{5} \mathrm{hdd}_{\mathrm{it}} \\
& +\mathrm{b}_{6} \mathrm{cdd}_{\mathrm{it}}+\mathrm{b}_{7 \mathrm{u}_{\mathrm{it}}}+\mathrm{b}_{8} \mathrm{Z}_{\mathrm{it}}+\mathrm{b}_{\mathrm{t}} \mathrm{t}+\mathrm{b}_{\mathrm{r}} \mathrm{r}+\mathrm{v}_{\mathrm{it}}+\mathrm{u}_{\mathrm{it}}
\end{aligned}
$$

where, $\mathrm{i}$ is the th Italian region and $\mathrm{t}$ is the theriod and we assume that $\mathrm{v}_{\mathrm{it}} \sim$ iid $\mathrm{N}\left(0, \sigma_{\mathrm{v}}^{2}\right)$ e $\mathrm{u}_{\mathrm{it}} \sim \mathrm{N}^{+}\left(\mathrm{b}_{\mathrm{z}} \mathrm{z}_{\mathrm{it}}, \sigma_{\mathrm{u}}^{2}\right)$. The results (Table 10) confirm the negative sign and the significance of the policy indicators fis, fis_ct and sind. The estimates of the model (17), including as usual time dummies $\left(\mathrm{bt}_{\mathrm{t}}\right)$ and regional dummies $\left(b_{r} r\right)$, have been repeated by introducing a delay $t-1$ (Table 11) confirming the negative sign and the significance of the financial variables fis and fis_ct:

$$
\begin{aligned}
& \mathrm{ed}_{\mathrm{it}}=\alpha+\mathrm{b}_{1} \mathrm{pe}_{\mathrm{it}-1}+\mathrm{b}_{2} \mathrm{pg}_{\mathrm{it}-1}+\mathrm{b}_{3} \mathrm{yd}_{\mathrm{it}-1}+\mathrm{b}_{4} \mathrm{pop}_{\mathrm{it}-1}+\mathrm{b}_{5} \mathrm{hdd}_{\mathrm{it}-1} \\
& +b_{6} c d d_{i t-1}+b_{7} s u_{i t-1}+b_{8} z_{i t-1}+b_{t} t+b_{r} r+v_{i t-1}+u_{i t-1}
\end{aligned}
$$

where, $\mathrm{i}$ is the th Italian region and $\mathrm{t}$ is the theriod and we assume that $\mathrm{v}_{\mathrm{it}} \sim$ iid $\mathrm{N}\left(0, \sigma_{\mathrm{v}}^{2}\right)$ e $\mathrm{u}_{\mathrm{it}} \sim \mathrm{N}^{+}\left(\mathrm{b}_{\mathrm{z}} \mathrm{z}_{\mathrm{it}}, \sigma_{\mathrm{u}}^{2}\right)$. Econometric evidence are consistent with Ecobonus, the greater building renovation mechanism pursued by the Italian government for more than a decade. Since 2011 over 2.6 million interventions have been carried out and over 3.6 million since the start of the Ecobonus mechanism (2007).

The classification of the top ten Italian regions based on the estimated level of average energy efficiency is reported in Table 12

Table 12. Classification of top 10 Italian region based on technical efficiency for fiscal and economic incentive policies

\begin{tabular}{cccc}
\hline Region & Area & $\begin{array}{c}\text { Technical } \\
\text { Efficiency } \\
\text { (Absolute value) }\end{array}$ & $\begin{array}{c}\text { Technical Efficiency } \\
\text { (Normalized value) }\end{array}$ \\
\hline Abruzzo & South & 0,981 & 1,000 \\
Lombardia & North & 0,970 & 0,989 \\
Calabria & South & 0,955 & 0,973 \\
Liguria & North & 0,942 & 0,960 \\
Umbria & Centre & 0,942 & 0,960 \\
Piemonte & North & 0,941 & 0,959 \\
Veneto & North & 0,941 & 0,958 \\
Campania & South & 0,940 & 0,958 \\
Toscana & Centre & 0,929 & 0,947 \\
Lazio & Centre & 0,910 & 0,927 \\
\hline
\end{tabular}

Most of the Italian municipalities of the top ten regions belongs to climate zones (The six climatic zones that characterize the Italian territory are distinguished within the D.P.R. n. 412 of 26 August 1993. The criterion underlying the zoning is based on degree days, that is the sum of the difference (only the positive one) between the internal indoor temperature (fixed by convention at $20^{\circ} \mathrm{C}$ ) and the average external temperature daily. Obviously, higher this number is, colder it will be in that particular Municipality. So, the municipalities will fall into the following intervals: A. municipalities with degree-days below $600^{\circ} \mathrm{C}$; B. municipalities with degree-days between 600 and $900^{\circ} \mathrm{C}$; C. municipalities with degree-days between 901 and $1400^{\circ} \mathrm{C}$; $\mathrm{D}$. municipalities with degree-days between 1401 and $2100^{\circ} \mathrm{C}$. E. municipalities with degree-days between 2101 and $3000^{\circ} \mathrm{C}$. F. municipalities with degree-days above $3000^{\circ} \mathrm{C}$.) characterized by low external average temperature values compared to internal indoor temperature (fixed by convention at $20^{\circ} \mathrm{C}$ ). For 
example, in Abruzzo the main town Aquila belongs to climatic zone E, in Lombardia the municipalities of Milano, Bergamo, Brescia, Como, Cremona, Lecco, Pavia, Varese belong to climate zone E, in Calabria the town of Vibo Valentia to climate zone E, in Liguria the capital Genova and La Spezia to climate zone D, Perugia the capital of Umbria to climate zone $\mathrm{E}$, in Piemonte the municipalities of Torino, Alessandria, Asti, Lodi, Novara, Sondrio, Pavia, Vercelli to climate zone E and the municipality of Cuneo to climate zone F, in Veneto the municipalities of Padova, Vicenza and Venezia to climate zone F, in Campania Avellino to climate zone E, in Toscana Arezzo to climate zone F and Firenze, Luca, Pia, Pistoia, Prato, Siena to climate zone E, in Lazio Rieti to climate zone F and Viterbo and Roma to climate zone E.

\subsection{Estimated energy demand model for the building sector with geographical dummies and interactions between variables}

Table 13. Estimated Energy demand for building sector with geographical dummies and with and without a t-1 delay

\begin{tabular}{|c|c|c|c|c|}
\hline \multirow{2}{*}{$\begin{array}{l}\text { Var. } \\
\text { pe }\end{array}$} & \multicolumn{2}{|c|}{ BC95 } & \multicolumn{2}{|c|}{ BC95 (t-1) } \\
\hline & $-.1785197 * *$ & $(.0786683)$ & $-.1714736^{*}$ & $(.0851606)$ \\
\hline pg & $.5724236 * * *$ & $(.1384914)$ & $.4205394 * * *$ & $(.1314492)$ \\
\hline yd & $.8815893 * * *$ & $(.1073638)$ & $.9183863 * * *$ & $(.198336)$ \\
\hline pop & $.9567053 * * *$ & $(.0286517)$ & $.9520047 * * *$ & $(.0225489)$ \\
\hline su & .1691421 & $(.3285906)$ & .3411806 & $(.309451)$ \\
\hline hdd & $.1674454 *$ & $(.089064)$ & $.3681387 * * *$ & $(.075215)$ \\
\hline \multirow[t]{2}{*}{ cdd } & .003986 & $(.027102)$ & .0245138 & $(.0270392)$ \\
\hline & \multicolumn{4}{|c|}{ Variable in the one sided error } \\
\hline$d_{s} s$ & l & $d_{s} s$ & I & \\
\hline d n & I & d n & I & \\
\hline d_c & -.5495176 & $(2.196032)$ & .4395286 & $(2.359936)$ \\
\hline s_fis_ct & I & $11 . s_{-}$fis_ct & I & \\
\hline n_fis_ct & $-.6872098 *$ & $(.4160177)$ & $-.5735906^{* *}$ & $(.1307107)$ \\
\hline c_fis_ct & .0072487 & $(.5814559)$ & .2645832 & $(.6423056)$ \\
\hline fis_ct & .1048284 & $(.3777484)$ & -.1099598 & $(.2879697)$ \\
\hline \multicolumn{5}{|c|}{ Variance parameters for the compound error } \\
\hline Sigma_u & $.46325 * *$ & $(.1484955)$ & $.5009072 * *$ & $(.1325168)$ \\
\hline \multirow[t]{2}{*}{ Lamda } & $9.358723 * * *$ & $(.1583042)$ & $18.2814 * * *$ & $(.1493399)$ \\
\hline & \multicolumn{2}{|c|}{ Time dummy: yes } & & \\
\hline \multirow{4}{*}{$\begin{array}{c}\text { Obs. } \\
\text { Info. Stat. }\end{array}$} & \multicolumn{2}{|c|}{152} & \multicolumn{2}{|c|}{133} \\
\hline & \multicolumn{2}{|c|}{ Prob $>$ chi $2=0.0000$} & \multicolumn{2}{|c|}{ Prob $>$ chi $2=$} \\
\hline & \multicolumn{2}{|c|}{ Log likelihood $=140.0429$} & \multicolumn{2}{|c|}{$0.0000 \mathrm{Log}$} \\
\hline & \multicolumn{2}{|c|}{ Wald chi2 $2(15)=22169.93$} & $\begin{array}{l}\text { likelihood } \\
\text { Wald chi2(1) }\end{array}$ & $\begin{aligned} & 118.6927 \\
= & 7.25 \mathrm{e}+08\end{aligned}$ \\
\hline
\end{tabular}

The estimates (Relationship between the aggregate energy demand of the building sector and the other variables for the ith Italian region in the $\mathrm{t}$-th period, with temporal dummies (btt) and geographical dummies (bgg) and the iteration between fiscal policy and the Dummy North (n_fis_ct), Dummy Centre (c_fis_ct) and Dummy South (s_fis_ct).), that include as usual time dummies (btt), were repeated by introducing the interaction between North, Centre, South dummies and the fiscal policies to analyse the relationship between regional disposable income and the efficacy of the fiscal policy promoting the energy efficiency investments:

$$
\begin{aligned}
& e d \$_{\mathrm{it}}=\alpha+b_{1} p e_{i t}+b_{2} p g_{\mathrm{it}}+b_{3} y d_{\mathrm{it}}+b_{4} p o p_{\mathrm{it}}+b_{5} h d d_{\mathrm{it}}+b_{6} c d d_{\mathrm{it}}+b_{7} s u_{i t} \\
& +b_{8} f_{i s c t_{\mathrm{it}}}+b_{9} W_{1 i t}+b_{10} W_{2 i t}+b_{11} W_{3 i t}+b_{t} t+b_{g} g+v_{i t}+u_{i t}
\end{aligned}
$$

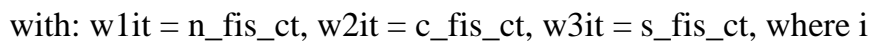
is the th Italian region and $t$ is the th period and we assume that $\mathrm{v}_{\mathrm{it}} \sim$ iid $\mathrm{N}\left(0, \sigma_{\mathrm{v}}^{2}\right)$ e $\mathrm{u}_{\mathrm{it}} \sim \mathrm{N}^{+}\left(\mathrm{b}_{\mathrm{z}} \mathrm{z}_{\mathrm{it}}, \sigma_{\mathrm{u}}^{2}\right)$. The results in Table 13 confirm the greater effectiveness of fiscal policies in Northern Italy because the mechanism is based on the expectation of future margin income necessary to deduct the expenditure incurred. In other words, a higher (expected) annual income favours the use of the tax incentive: notoriously, the Northern regions show higher average per capita income values than those of the Central and South regions.

\subsection{Estimated energy demand model for the building sector an application of Energy Environmental Kuznets Curve (EKC)}

Energy EKC has been applied to understand the relationship between per capita income and energy consumption.

The equation estimated in the study is the logarithmic transformation of (9) which identifies the relationship between the aggregate energy demand of the buildings sector and the other variables indicated for the $\mathrm{i}$-th Italian region for the $\mathrm{t}$-th period:

$$
\begin{aligned}
& \mathrm{e}_{\mathrm{it}}=\mathrm{A}_{\mathrm{it}}+\beta_{1} \mathrm{y}_{\mathrm{it}}+\beta_{2} \mathrm{y}_{\mathrm{it}}^{2}+\beta_{3} \mathrm{y}^{3} \mathrm{it}+\beta_{4} \mathrm{Zit} \\
& +\beta_{5} d p o p_{\mathrm{it}}+\beta_{6} \mathrm{~S}_{-} \mathrm{km}^{2} \mathrm{it} .
\end{aligned}
$$

The estimation results of the energy demand model for the building sector applying the Energy EKC framework with the Stochastic Frontier Approach and the Generalized List

\begin{tabular}{|c|c|c|c|c|}
\hline \multirow{2}{*}{$\begin{array}{l}\text { Var. } \\
\text { ygm }\end{array}$} & \multicolumn{2}{|c|}{ SFA BC95 } & \multicolumn{2}{|c|}{ FGLS } \\
\hline & $57.1108 * *$ & (18.98619) & $5.178386 * *$ & (2.069029) \\
\hline $\mathrm{Ygm}^{2}$ & $-8.071158 * *$ & $(2.5573)$ & $-.7414209 * *$ & $(.2914561)$ \\
\hline $\mathrm{Ygm}^{3}$ & $.3800141 * * *$ & $(.1142582)$ & $.035252 * *$ & $(.0135825)$ \\
\hline sind & & & $-.0854235 * * *$ & $(.0071162)$ \\
\hline dpop & & & $.9869607 * * *$ & $(.0176068)$ \\
\hline $\mathrm{Km}^{2}$ & & & $1.092365 * * *$ & $(.015702)$ \\
\hline \multicolumn{5}{|c|}{ Variable in the one sided error } \\
\hline sind & I & I & & \\
\hline dpop & -12.9799 & $(35.29347)$ & & \\
\hline $\mathrm{Km}^{2}$ & -11.71294 & $(32.40844)$ & & \\
\hline Obs. & \multicolumn{2}{|c|}{82} & \multicolumn{2}{|c|}{82} \\
\hline Info. & \multirow{2}{*}{\multicolumn{2}{|c|}{$\begin{array}{c}\text { Prob }>\text { chi } 2=0.0000 \mathrm{Log} \\
\text { likelihood }=-85.9077\end{array}$}} & \multirow{3}{*}{\multicolumn{2}{|c|}{$\begin{array}{c}\text { Waldchi } 2(7)=45014.38 \text { Log } \\
\text { likelihood }=88.29152 \\
\text { Prob }>\text { chi } 2=0.0000\end{array}$}} \\
\hline Stat. & & & & \\
\hline & Wald chi2(5) & $=175974.50$ & & \\
\hline
\end{tabular}
Squares are shown in Table 14.

Table 14. Energy ECK - relationship between income and energy consumption

For estimates carried out with Generalized Least Squares method can be observed that, since the estimated coefficient $(\beta 4)$ relating to adhesion to the Covenant (sind) is negative, the actions undertaken by the joining municipalities produce positive results in terms of reducing electricity consumption.

It can be observed an inverted $U$ trend from the estimates of the coefficients $(\beta 1, \beta 2$ and $\beta 3)$ related to the geometric mean of disposable income (Yd).

In the first phase, as disposable income increases, energy consumption increases, while beyond a specific threshold, as disposable income increases, there is a decrease in energy consumption. This effect, in the first phase of growth, can be traced back to the need to ensure an adequate level of heating and cooling of buildings.

The European Commission reports that around 34 million Europeans are unable to afford keeping their home adequately 
heated. The share of families in energy poverty condition is approximately $8 \%$ of the total, with an increasing trend in recent years (reaching in 2016 a value of approximately $8.6 \%$, equal to 2.2 million families, this value would be more or less confirmed in 2017). In the descending phase, the phenomenon can be attributed to the greater awareness of citizens and the entire community (partly due to the adhesion to the Covenant of Mayors initiative), to environmental issues and specifically to measures relating to energy efficiency (i.e. buildings renovation).

\section{CONCLUSIONS AND POLICY IMPLICATIONS}

The aim of this research activity was to evaluate the effectiveness of the main energy efficiency policy measures in Italy aimed at promoting the reduction of energy consumption. The long term building renovation strategy in addition to the increasing level of energy savings and the reducing of greenhouse gas emissions, contributes to increase the level of "green" employment for companies and workers and to favour some social benefits such as the reduction of "energy poverty", enhancing the quality of life for people living in and using the buildings.

Following the approach proposed by Filippini and Hunt (2011, 2012, 2014) this paper employs a frontier demand energy model to estimate the 'underlying energy efficiency' of the building sector for each Italian region over the period 2010 to 2017.

The Stochastic Frontier econometric estimates confirms the effectiveness of the Ecobonus and Thermal Account mechanisms and partially the adherence to the Covenant of Mayors in favouring the energy efficiency processes that lead to the reduction of energy consumption. From the regional models analysed 16 we can observe that the Ecobonus and the Thermal Account mechanism provide a significant boost of energy efficiency investments in the building sector (real estate, public administration, schools, sports facilities and more). The empirical data (from ENEA, "Annual Energy Efficiency Reports" and GSE "Annual Activity Report"), confirms that in Italy over two million energy renovation interventions were carried out in residential and public buildings thanks to the fiscal and economic incentive measures. Energy savings of approximately $7.100 \mathrm{GWh} /$ year and investments for over 20 billion euros have been achieved.

The estimated average energy efficiency level based on the Battese and Coelli (1995) model shows a potential for a decrease in the building sector. The variation in energy efficiency between the 20 Italian Region is mainly due to different economic and geographic conditions. In terms of energy efficiency performance generally the North part of Italy is more performing. The greater effectiveness of fiscal and economic measures in this zone is confirmed by the econometric estimate and it is mainly due to several reasons among which the climatic conditions within the same region and between the 20 Italian regions, the distribution of disposable income and the type of energy efficiency interventions carried out.

The results are also found to be in line with results of previous study of Filippini et al. [2] where the most effective policy instruments for energy improvements in EU member states were the financial incentives.

The enhanced mechanism of tax deductions (SuperEcobonus), raising the fiscal incentives to $110 \%$ and providing for the possibility of credit transfer, could significantly increase the energy requalification of condominiums, a category from which a significant contribution is expected in the coming years.

The effectiveness of the policy measure of the Covenant of Mayors is partial. The results of the estimates confirm that adherence to the Covenant of Mayors by the municipalities does not always lead to the implementation of the actions envisaged in the Action Plan. The main barriers encountered by the municipalities are the identification of the appropriate sources of funding, excessive bureaucracy of some local administrations, the lack of stability and continuity of some local government and some other additional barriers. Probably the combination with other policy, mechanism and tools would contribute to a greater effectiveness of this voluntary initiative.

\section{REFERENCES}

[1] Filippini, M., Hunt, L.C. (2011). Energy demand and energy efficiency in the OECD countries: A stochastic demand frontier approach. The Energy Journal, 32(2). https://doi.org/10.5547/ISSN0195-6574-EJ-Vol32-No23

[2] Filippini, M., Hunt, L.C., Zorić, J. (2014). Impact of energy policy instruments on the estimated level of underlying energy efficiency in the EU residential sector. $\begin{array}{llll}\text { Energy } & \text { 73-81. }\end{array}$ https://doi.org/10.1016/j.enpol.2014.01.047

[3] Otsuka, A., Goto, M. (2015). Estimation and determinants of energy efficiency in Japanese regional economies. Regional Science Policy \& Practice, 7(2): 89101. https://doi.org/10.1111/rsp3.12058

[4] Schmidt, P. (1976). On the statistical estimation of parametric frontier production functions. Review of Economics and Statistics, 58: 238-239.

[5] Aigner, D.J., Amemiya, T., Poirier, D.J. (1976). On the estimation of production frontiers: Maximum likelihood estimation of the parameters of a discontinuous density function. International Economic Review, 377-396. https://doi.org/10.2307/2525708

[6] Filippini, M., Hunt, L.C. (2012). US residential energy demand and energy efficiency: A stochastic demand frontier approach. Energy Economics, 34(5): 1484-1491. https://doi.org/10.1016/j.eneco.2012.06.013

[7] Deaton, A., Muellbauer, J., 1980. Economics and Consumer Behavior. Cambridge University Press, Cambridge.

[8] Adom, P.K. (2015). Asymmetric impacts of the determinants of energy intensity in Nigeria. Energy Economics, $\quad 49$ 570-580. https://doi.org/10.1016/j.eneco.5.03.027

[9] Adom, P.K. (2015). Determinants of energy intensity in South Africa: Testing for structural effects in parameters. Energy, 89: 334-346. https://doi.org/10.1016/j.energy.2015.05.125

[10] Adom, P.K., Kwakwa, P.A. (2014). Effects of changing trade structure and technical characteristics of the manufacturing sector on energy intensity in Ghana. Renewable and Sustainable Energy Reviews, 35: 475483. https://doi.org/10.1016/j.rser.2014.04.014

[11] Azhgaliyeva, D., Liu, Y., Liddle, B. (2020). An empirical analysis of energy intensity and the role of policy instruments. Energy Policy, 145: 111773. 
https://doi.org/10.1016/j.enpol.2020.111773

[12] Filipovic, S., Verbic, M., Radovanovic, M. (2015). Determinants of energy intensity in the European Union: a panel data analysis. Energy, 92: 547-555. https://doi.org/10.1016/j.energy.2015.07.011

[13] Zhang, F. (2013). The energy transition of the transition economies: An empirical analysis. Energy Economics, 40:

679-686 https://doi.org/10.1016/j.eneco.2013.09.001

[14] Zhang, D., Cao, H., Wei, Y.M. (2016). Identifying the determinants of energy intensity in China: A Bayesian averaging approach. Applied Energy, 168: 672-682. https://doi.org/10.1016/j.apenergy.2016.01.134

[15] Battese, G.E., Coelli, T.J. (1995). A model for technical inefficiency effects in a stochastic frontier production function for panel data. Empirical Economics, 20(2): 325-332. https://doi.org/10.1007/BF01205442

[16] Bertoldi, P., Mosconi, R. (2015). The impact of energy efficiency policies on energy consumption in the EU Member States: A new approach based on Energy Policy indicators.

[17] Panayotou, T. (1993). Empirical tests and policy analysis of environmental degradation at different stages of economic development (No. 992927783402676). International Labour Organization.

[18] Kuznets, S. (1955). Economic growth and income inequality. The American Economic, 45(1): 1-28.
[19] Luzzati, T., Marco, O., Gucciardi, G. (2017). A multiscale analysis of the EKC for energy use and $\mathrm{CO}_{2}$ emissions. In BIWAES 2017: Energy futures, environment and well-being, Verlag der Technischen Universitaet Graz, 141-147.

[20] Pablo-Romero, M.D.P., Pozo-Barajas, R., SánchezBraza, A. (2016). Analyzing the effects of Energy Action Plans on electricity consumption in Covenant of Mayors signatory municipalities in Andalusia. Energy Policy, 99: 12-26. https://doi.org/10.1016/j.enpol.2016.09.049

[21] Saboori, B., Sulaiman, J. (2013). Environmental degradation, economic growth and energy consumption: Evidence of the environmental Kuznets curve in Malaysia. Energy Policy, 60: 892-905. https://doi.org/10.1016/j.enpol.2013.05.099

[22] Zilio, M., Recalde, M. (2011). GDP and environment pressure: the role of energy in Latin America and the Caribbean. Energy Policy, 39(12): 7941-7949. https://doi.org/10.1016/j.enpol.2011.09.049

[23] Amemiya, T. (1973). Regression analysis when the dependent variable is truncated normal. Econometrica: Journal of the Econometric Society, 997-1016. https://doi.org/10.2307/1914031

[24] Tsemekidi Tzeiranaki, S., Bertoldi, P., Diluiso, F., Castellazzi, L., Economidou, M., Labanca, N., Zangheri, P. (2019). Analysis of the EU residential energy consumption: Trends and determinants. Energies, 12(6): 1065. 